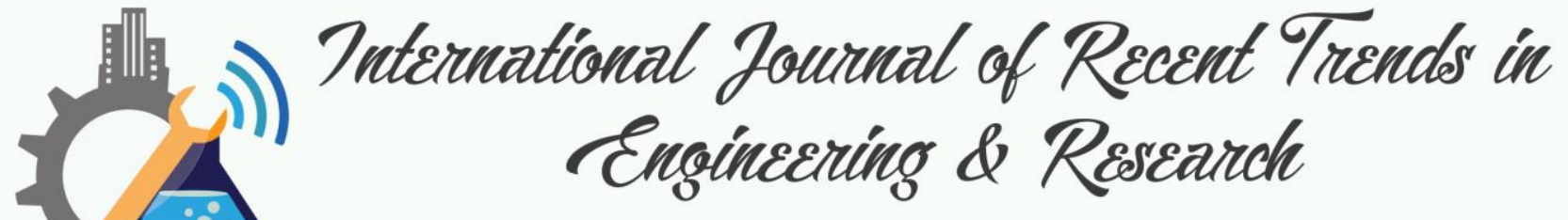

\title{
Expert System of Catfish Disease Determinant Using Certainty Factor Method
}

\author{
Isnar Sumatorno', Diki Arisandi', Andysah Putera Utama Siahaan ${ }^{3}$, Mesran $^{4}$ \\ ${ }^{1,3}$ Faculty of Computer Science, Universitas Pembangunan Panca Budi, Medan, Indonesia \\ ${ }^{2}$ Faculty of Engineering, Department of Informatics, Universitas Abdurrab, Pekanbaru, Indonesia \\ ${ }^{4}$ Department of Computer Engineering, STMIK Budi Darma, Medan, Indonesia \\ ${ }^{3}$ Ph.D. Student of School of Computer and Communication Engineering, Universiti Malaysia Perlis, \\ Kangar, Malaysia
}

\begin{abstract}
Catfish is one type of freshwater fish. This fish has a good taste. In the cultivation of these fish, many obstacles need to be faced. Because living in dirty water, this type of fish is susceptible to disease. Many symptoms arise during the fish cultivation process; From skin disease to physical. Catfish farmers do not know how to diagnose diseases that exist in their livestock. This diagnosis serves to separate places between good and sick catfish. The goal is that the sale value of the fish is high. Catfish that have diseases will be sold cheaper to be used as other animal feed while healthy fish will be sold to the market or exported to other countries. Diagnosis can be done by expert system method. The algorithm of certainty factor is one of the good algorithms to determine the percentage of possible fish disease. This algorithm is very helpful for farmers to improve catfish farming.
\end{abstract}

Keywords - Certainty Factor, Expert System, Catfish

\section{INTRODUCTION}

Catfish is one type of fish that can live in high-density water [8]. This fish has a feed conversion rate to be a good body weight. With this nature, catfish farming will be very profitable if done intensively. There are two segments of catfish farming business, seeding, and enlargement. The seeding segment aims to produce catfish seeds, while the enlargement segment aims to produce catfish ready for consumption. Fish disease is one of the obstacles and obstacles in the business of cultivation. Illness can cause death in fish cultivation. The high mortality rate in cultivation efforts will have an impact on fish production. So the income figure becomes lower compared to the amount of capital spent making ponds or ponds, and the purchase of feed and so forth then will cause a decrease in the price of sick fish compared to normal conditions. Based on the causes, diseases in fish can be divided into two, namely due to infection and non-infectious diseases. Pathogen infection causes infectious diseases in the host's body. Catfish will be susceptible to disease if in a state of weakness, lack of food or injuries due to poor handling. The disease can be caused by small beasts attached to the gills and skin of fish bodies, such as Copepoda, Protozoa, leeches and so on.

However, in the process of catfish cultivation, not all breeders know the type of disease that is attacking their livestock. The real problem can be overcome by knowing the disturbing symptoms in his life. However, many symptoms must be analyzed by the breeder. Expert systems are one solution that can help solve question-based problems [1][2][3]. The use of an expert system is beneficial to anticipate the early disease that attacks the catfish tie. Certainty factor can help to determine how big the disease that attacks the fish. Productivity is expected to increase after the application of this method to the catfish. 


\section{THEORIES}

\section{A. Catfish Diseases}

Diseases in catfish are more often characterized by physical changes in the fish. This disease causes catfish is not feasible to be cultivated, thus lowering the sales market [4][5]. Here are some types of diseases that often attack catfish:

1. White Spot

The cause of this disease is because of protozoa. Its name is Ichthyophthirius Multifiliis. If it is in the body of the fish, it will not be visible to the naked eye because of its very small size. However, its presence often accumulates then it will look a kind of white spots on the fish body. Protozoa usually stick under mucous membranes, fish that have been attacked will be visible wounds along with white spots and will experience bleeding in the gills and fins.

\section{Bacteria}

Bacteria are a serious threat to fish farmers because bacteria include malignant disease. Fish infected with bacteria should first be treated and then prevented against incoming bacteria. It aims to keep the fish from spreading the disease to other animals. But not all bacteria can be cured. If the condition of the fish is very critical, eating the fish can not be saved anymore.

\section{Lernaea}

Lernaea is a large fish parasite that often attacks the fish. Ticks are more common in fish that are kept in livestock ponds. It attacks the fish from seed to parent by sucking the liquid from the host's body. Injuries caused by teeth can cause secondary infections, such as a virus, fungal and bacterial attacks, and will cause skinny and wounded fish.

\section{Fungus}

Fish will be susceptible to fungus if injured in the body. Fish will be susceptible to fungus in ponds that are in the process of decomposition. Characteristics of fish affected by the fungus are characterized by fine hairs that grow around the wound. Fungal diseases do not harm the condition of fish. However, if not done treatment, the fungus will damage the health of the fish so that the fish will die.

\section{B. Certainty Factor}

Buchanan Shortliffe introduced the certainty factor algorithm in the making of MYCIN [7]. It is the value of the clinical parameters given by MYCIN to indicate the magnitude of the trust. This algorithm is used to measure how confident the analysis of a problem case so that the solution can be achieved well. This algorithm is often used for solving cases involving surveys and questions about a symptom or indication. This method can only process two weights in one calculation. Mixing weights for more than two are not provided in this method. According to David McAllister, Certainty Factor is a method to prove whether a fact is surely or uncertain in the form of a metric that is usually used in expert systems. This method is perfect for expert systems that diagnose something uncertain.

Certainty Factor is defined as the following equation:

$$
\mathrm{CF}(\mathrm{H}, \mathrm{E})=\mathrm{MB}(\mathrm{H}, \mathrm{E})-\mathrm{MD}(\mathrm{H}, \mathrm{E})
$$


$\mathrm{CF}(\mathrm{H}, \mathrm{E})$ is Certainty Factor of hypothesis $\mathrm{H}$ influenced by symptoms $\mathrm{E}$. The magnitude of CF ranges from -1 to 1 . The value of -1 shows absolute mistrust while the value 1 indicates absolute trust. MB $(\mathrm{H}, \mathrm{E})$ is the measure of increased belief on $\mathrm{H}$ hypothesis influenced by symptoms of $\mathrm{E} . \mathrm{MD}(\mathrm{H}, \mathrm{E})$ is the measure of increased disbelief of $\mathrm{H}$ hypothesis influenced by symptoms $\mathrm{E}$. The basic form of the formula certainty factor is indicated by the following equation:

$$
\mathrm{CF}(\mathrm{H}, \mathrm{e})=\mathrm{CF}(\mathrm{E}, \mathrm{e}) * \mathrm{CF}(\mathrm{H}, \mathrm{E})
$$

Where:

$\mathrm{CF}(\mathrm{H}, \mathrm{e}) \quad$ : $\quad$ certainty factor hypothesis influenced by the evidence e.

$\mathrm{CF}(\mathrm{E}, \mathrm{e})$ : $\quad$ certainty factor evidence $\mathrm{E}$ influenced by the evidence e.

$\mathrm{CF}(\mathrm{H}, \mathrm{E}): \quad$ certainty factor hypothesis when $\mathrm{CF}(\mathrm{E}, \mathrm{e})=1$

If all the antecedent evidence is known with certainty then the equation will be:

$$
\mathrm{CF}(\mathrm{E}, \mathrm{e})=\mathrm{CF}(\mathrm{H}, \mathrm{E})
$$

In the application, $\mathrm{CF}(\mathrm{H}, \mathrm{E})$ is the value of certainty given by the expert to a rule, while $\mathrm{CF}(\mathrm{E}, \mathrm{e})$ is the value of trust given by the user to the symptoms.

\section{Proposed Work}

Determination of disease based on existing knowledge base in the expert system. It serves to determine the conclusions obtained from the analysis. The results obtained after the user interacts with the expert system is by answering questions posed by the expert system. An expert will prepare some questions to be asked to catfish farmers. The answers given will be obtained to get the correct answer. Many symptoms can cause the death of catfish. In this study, the authors use only 16 symptoms to determine the disease suffered by the catfish as shown in Table 1.

Table 1. Symptoms

\begin{tabular}{|c|c|l|c|}
\hline No. & Symptom & \multicolumn{1}{|c|}{ Remark } & Weight \\
\hline 1 & S1 & Dark Color & 0,7 \\
\hline 2 & S2 & Gasping Breath & 0,8 \\
\hline 3 & S3 & Bloated Skin & 0,8 \\
\hline 4 & S4 & Abdominal Swelling & 0,8 \\
\hline 5 & S5 & Spinning & 0,7 \\
\hline 6 & S6 & White Spots & 0,7 \\
\hline 7 & S7 & Fine Yarn & 0,8 \\
\hline 8 & S8 & Egg Attack & 0,7 \\
\hline 9 & S9 & Very Weak & 0,6 \\
\hline 10 & S10 & Floating & 0,8 \\
\hline 11 & S11 & Rubbing & 0,8 \\
\hline 12 & S12 & Damaged Gills & 0,8 \\
\hline 13 & S13 & Slow Growth & 0,7 \\
\hline 14 & S14 & Animea & 0,7 \\
\hline 15 & S15 & Spotting Wound & 0,8 \\
\hline 16 & S16 & Ulcers & 0,7 \\
\hline
\end{tabular}


There are seven diseases in catfish are discussed in this study. The diseases are Pseudomonas Hydrophilia, Tuberculosis, Saprolegnia, White spots, Trematoda, Parasite, and Ulcers. Each disease will have its symptoms. Table 2 describes the types of diseases that may attack catfish farmers.

Table 2. Diseases

\begin{tabular}{|c|c|l|}
\hline No. & Disease & \multicolumn{1}{|c|}{ Remark } \\
\hline 1 & D1 & $\begin{array}{l}\text { Pseudomonas } \\
\text { hydrophilia }\end{array}$ \\
\hline 2 & D2 & Tuberculosis \\
\hline 3 & D3 & Saprolegnia \\
\hline 4 & D4 & White spots \\
\hline 5 & D5 & Trematoda \\
\hline 6 & D6 & Parasite \\
\hline 7 & D7 & Ulcers \\
\hline
\end{tabular}

Table 3 describes what symptoms will occur for a particular disease. Each disease has more than one symptom. Catfish can have two diseases simultaneously where the selected symptoms result in more than one disease being selected.

Table 3. Combination of Disease and Symptoms

\begin{tabular}{|c|c|l|}
\hline No. & Disease & \multicolumn{1}{|c|}{ Symtoms } \\
\hline 1 & D1 & S1, S2, S3, S10 \\
\hline 2 & D2 & S1, S4, S5, S6, S10 \\
\hline 3 & D3 & S7, S8 \\
\hline 4 & D4 & S6, S9, S10, S11 \\
\hline 5 & D5 & S9, S12 \\
\hline 6 & D6 & S13, S14 \\
\hline 7 & D7 & S15, S16 \\
\hline
\end{tabular}




\section{EVALUATION}

Testing will be done in this section. Three test data will be performed to gain results. Each data has different symptoms. Each disease will have different values. Table 4 is an example of test data on disease symptoms in catfish.

Table 4. Certainty Factor Test

\begin{tabular}{|c|c|l|c|c|c|}
\hline No. & Symptom & \multicolumn{1}{|c|}{ Remark } & T1 & T2 & T3 \\
\hline 1 & S1 & Dark color & $\checkmark$ & & \\
\hline 2 & S2 & Bloated skin & $\checkmark$ & & $\checkmark$ \\
\hline 3 & S3 & Gasping breath & $\checkmark$ & $\checkmark$ & $\checkmark$ \\
\hline 4 & S4 & Abdominal swelling & & & \\
\hline 5 & S5 & Spin or bevel & $\checkmark$ & & \\
\hline 6 & S6 & White spot & & & $\checkmark$ \\
\hline 7 & S7 & Fine yarn & & $\checkmark$ & \\
\hline 8 & S8 & Egg attack & & $\checkmark$ & \\
\hline 9 & S9 & Very weak & & & \\
\hline 10 & S10 & Floating & & $\checkmark$ & \\
\hline 11 & S11 & Rubbing & & $\checkmark$ & \\
\hline 12 & S12 & Damaged gills & & & \\
\hline 13 & S13 & Slow growth & & & $\checkmark$ \\
\hline 14 & S14 & Animea & & & $\checkmark$ \\
\hline 15 & S15 & Ulcers & & & $\checkmark$ \\
\hline 16 & S16 & Spotting wound & & \\
\hline
\end{tabular}

Table 5. Certainty Factor Value

\begin{tabular}{|c|c|l|c|c|c|}
\hline No. & Symptom & \multicolumn{1}{|c|}{ Remark } & T1 & T2 & T3 \\
\hline 1 & S1 & Dark Color & 0.7 & & \\
\hline 2 & S2 & Gasping Breath & 0.8 & & 0.8 \\
\hline 3 & S3 & Bloated Skin & 0.8 & 0.8 & 0.8 \\
\hline 4 & S4 & Abdominal Swelling & & & \\
\hline 5 & S5 & Spinning & 0.7 & & \\
\hline 6 & S6 & White Spots & & & 0.7 \\
\hline 7 & S7 & Fine Yarn & & 0.8 & \\
\hline 8 & S8 & Egg Attack & & 0.7 & \\
\hline 9 & S9 & Very Weak & & & \\
\hline 10 & S10 & Floating & & 0.8 & \\
\hline 11 & S11 & Rubbing & & & 0.8 \\
\hline 12 & S12 & Damaged Gills & & & 0.7 \\
\hline 13 & S13 & Slow Growth & & & 0.8 \\
\hline 14 & S14 & Animea & & & 0.7 \\
\hline 15 & S15 & Spotting Wound & & \\
\hline 16 & S16 & Ulcers & & \\
\hline
\end{tabular}


Table 6. Certainty Factor Value of T1

\begin{tabular}{|c|c|l|}
\hline No. & Disease & \multicolumn{1}{|c|}{ Symptoms } \\
\hline 1 & D1 & $0.7,0.8,0.8,0$ \\
\hline 2 & D2 & $0.7,0,0.7,0,0$ \\
\hline 3 & D3 & 0,0 \\
\hline 4 & D4 & $0,0,0,0$ \\
\hline 5 & D5 & 0,0 \\
\hline 6 & D6 & 0,0 \\
\hline 7 & D7 & 0,0 \\
\hline
\end{tabular}

$$
\begin{aligned}
\text { D1 } & =0.7-(0.8 *(1-0.7)) \\
& =0.94 \\
& =0.8-(0.94 *(1-0.8)) \\
& =0.612 \\
\text { D2 } & =0.7-(0.7 *(1-0.7)) \\
& =0.91 \\
\text { D3 } & =0 \\
\text { D4 } & =0 \\
\text { D5 } & =0 \\
\text { D6 } & =0 \\
\text { D7 } & =0
\end{aligned}
$$

D2 has the greatest chance of the first test. It can be seen that D1 has a value smaller than D2. Two diseases may arise in this test. D1 has a value of 0.612 while D2 has a value of 0.91 . Catfish located in this position is likely infected with Pseudomonas Hydrophilia and Tuberculosis.

Table 7. Certainty Factor Value of T2

\begin{tabular}{|c|c|l|}
\hline No. & Disease & \multicolumn{1}{|c|}{ Symptoms } \\
\hline 1 & D1 & $0,0,0.8,0$ \\
\hline 2 & D2 & $0,0,0,0,0.8$ \\
\hline 3 & D3 & $0.8,0.7$ \\
\hline 4 & D4 & $0,0,0.8,0$ \\
\hline 5 & D5 & $0,0.8$ \\
\hline 6 & D6 & 0,0 \\
\hline 7 & D7 & 0,0 \\
\hline
\end{tabular}

$$
\begin{aligned}
\mathrm{D} 1 & =0 \\
\mathrm{D} 2 & =0 \\
\mathrm{D} 3 & =0.8-(0.7 *(1-0.8)) \\
& =0.94
\end{aligned}
$$


D4 $=0$
D5 $=0$
D6 $=0$
D7 $=0$

In Table 7 it can be seen that D3 is the greatest value of all possibilities so that the catfish is likely to catch Saprolegnia disease.

Table 8. Certainty Factor Value of T3

\begin{tabular}{|c|c|l|}
\hline No. & Disease & \multicolumn{1}{|c|}{ Symtoms } \\
\hline 1 & D1 & $0,0.8,0.8,0$ \\
\hline 2 & D2 & $0,0,0,0.8,0$ \\
\hline 3 & D3 & 0,0 \\
\hline 4 & D4 & $0.7,0,0,0.8$ \\
\hline 5 & D5 & 0,0 \\
\hline 6 & D6 & $0,0.7$ \\
\hline 7 & D7 & $0.8,0.7$ \\
\hline
\end{tabular}

$\mathrm{D} 1=0.8-(0.8 *(1-0.8))$

$=0.96$

$\mathrm{D} 2=0$

$\mathrm{D} 3=0$

D4 $=0.7-(0.8 *(1-0.7))$

$=0.94$

$\mathrm{D} 5=0$

$\mathrm{D} 6=0$

$\mathrm{D} 7=0.8-(0.7 *(1-0.8))$

$=0.94$

The last test as shown in Table 8 states there are many possible diseases. D1, D4, and D7 are diseases that arise. Each disease has different values as well. D1 has a value of 0.96, D4 and D7 have the same value of 0.94. This test states that catfish has at once three diseases, Pseudomonas Hydrophilia, White Spots, and Ulcers.

\section{CONCLUSION}

A questionnaire is a tool that can affect the Certainty Factor value. The more precise the answer to the question being asked, the more accurately the value obtained. Farmers can help develop their livestock cultivation by knowing the types of diseases that exist in their animals. The weakness of this method is obtained when the attached symptom is small. An expert must carefully make a list of symptoms and diseases associated with the condition of the catfish so that the value obtained is accurate. By understanding veterinary science, this can help determine the symptoms and types of diseases in catfish. 


\section{REFERENCES}

[1] Z. Tharo and A. P. U. Siahaan, "Profile Matching in Solving Rank Problem," IOSR Journal of Electronics and Communication Engineering, vol. 11, no. 5, pp. 73-76, 2016.

[2] A. P. U. Siahaan, "Fuzzification of College Adviser Proficiency Based on Specific Knowledge," International Journal of Advanced Research in Computer Science and Software Engineering, vol. 6, no. 7, pp. 164-168, 2016.

[3] H. A. Hasibuan, R. B. Purba and A. P. U. Siahaan, "Productivity Assessment (Performance, Motivation, and Job Training) Using Profile Matching," SSRG International Journal of Economics and Management Studies, vol. 3, no. 6, 2016.

[4] O. F. Foline, A. M. Rachael, B. E. Iyabo and A. E. Fidelis, "Proximate Composition of Catfish Smoked in Nigerian Stored Products Research Institute," International Journal of Fisheries and Aquaculture, vol. 3, no. 5, pp. 96-98, 2011.

[5] M. Mbalassa, M. Nshombo, M. E. Kateyo, L. Chapman, J. Efitre and G. Bwanika, "Identification of Migratory and Spawning Habitats of Clarias Gariepinus in Lake Edward, Ishasha River Watershed, Albertine Rift Valley, East Africa," International Journal of Fisheries and Aquatic Studies, vol. 2, no. 3, pp. 128-138, 2015.

[6] E. Turban, Decision Support System and Expert Systems, USA: Prentice Hall International Inc., 1995.

[7] Kusrini, "Question Quantification to Obtain User Certainty Factor in Expert System Application for Disease," in Proceedings of the International Conference on Electrical Engineering and Informatics, Bandung, 2007.

[8] Dewita and Syahrul, "Quality Assessment of Fish Protein Concentrate from Catfish," IOSR Journal of Environmental Science, Toxicology and Food Technology, vol. 9, no. 9, pp. 20-23, 2015. 